Global Conferences Series:

Social Sciences, Education and Humanities (GCSSSEH), Volume 2, 2019

The $2^{\text {nd }}$ International Conference on Sustainable Development \& Multi-Ethnic Society

DOI: https://doi.org/10.32698/GCS.01114

\title{
The Implementation of History Curriculum in
} Primary School with Environmental Influence and Knowledge in Enforcing Self-Identity as a Malaysian

\author{
Zunaida Zakaria ${ }^{1}$, Abdul Razaq Bin Ahmad ${ }^{2} \&$ Mohd Mahzan Awang ${ }^{3}$ \\ ${ }^{1}$ Ministry of Education, MALAYSIA \\ ${ }^{23}$ Faculty of Education, The National University of Malaysia, MALAYSIA \\ E-mail: zunaida73@gmail.com
}

\begin{abstract}
This paper discusses the implementation of the primary school history curriculum with the support of the environment and knowledge to realize the nation's aspirations, especially in promoting Malaysian self- identity among primary school students. The implementation of this primary school history curriculum is supported by the availability of infrastructure, management administration, content knowledge and pedagogy as well as history-based thinking skills assessed from the teacher's perspective. The implementation of this primary school history curriculum is evaluated on the aspects of effective history teaching methods, the use of textbooks, teaching aids where the assessment in this study involving both teachers and students. In addition, the self-identity practice as a Malaysian was assessed from the perspective of students for aspects comprises of understanding human behaviour, actions and consequences in history, the uniqueness of our homeland, glory and patriotic citizens as well as understanding of democratic practices. History subjects have become a core subject that all students must learn in the Primary School Curriculum from year 4 in the second grade. The role of this history subject is to underpin and nurture students' patriotic souls with their knowledge on historical values. This paper therefore seeks to look at the extent to which the implementation of the history curriculum of the primary school subjects as a core subject in the primary school in implementing Malaysian citizenship practices with the support of the environment and the knowledge of teachers. This paper also discusses the position and goals of primary school history subjects. Therefore, it is vital for these younger generation to implement self-identity as a practice to create a proud citizen. This paper will also widely explore the studied constructs.
\end{abstract}

Keywords: Primary School Standard Curriculum (KSSR), self-identity, Malaysian, environment and teacher knowledge

Copyright ( $) 2019$, the Authors. Published by Redwhite Press.

Page | 303

This is an open access article under the CC BY-NC license

(http://creativecommons.org/licenses/by-nc/4.0). 


\section{Introduction}

In the early stages, History subject that was introduced in Malay-streamed schools was more towards classical Malay literature. The British did not emphasize on local history in the community in Malaya as it might undermine the political and economic interests. Only after the country achieved independence did the British curriculum influence diminished (Maharom Mahmood, 2001). History on India and China ended when the 1956 Razak Report was submitted to ensure that a similar teaching and examination was implemented for the sake of racial harmony in the country.

After the Second World War, the History curriculum began to emphasize on unity and racial integration. In 1973, there was a talk of reviewing the History curriculum. The existing curriculum is seen as too broad and not localised (Siti Zainun Mat, 1998; 1990). Several forums such as the Malaysian Cultural Congress 1971, the Malaysian History Seminar 1 and 11 held in 1973 and 1974 (Siti Zainun Mat, 1988 and 1990) were held to discuss it.

In this context, it is hoped History subject will serve as a catalyst to create shared memories and as a reference for national consciousness among Malaysians. Up to this point, (Razak Report, 1956 and Rahman Talib Report, 1960) did not incorporate philosophy into the National Education Policy. What is important at this time is to unite all the races in Malaysia through the widespread use of the Malay language and practice Malaysia-shaped culture (Mohd. Salleh Lebar, 1996).

The transformation of History curriculum is not only in the curriculum aspect, but also in the status of the subject in schools. It is to ensure that the goals of nation building as well as national sovereignty will be met. Since 1989 , History subject is compulsory regardless of the type of the school. This means that in 1993, all Form Five students took History subject under their Malaysian Certificate of Education (SPM) examination (Report of Teaching of History in the School, Ministry of Education Malaysia 1991; Ministry of Education Malaysia, 1990a). Previously, History subjects were only an elective subject. This is not surprising because the aim of the History subject is to emphasize on the appreciation of creation or the creation of man in ancient times (Musa Daia, 1978).

\section{Primary School History Curriculum (KSSR)}

The history curriculum of the Primary School supports the noble ideas in providing a relevant and up-to-date curriculum for the excellent generation in line with the National Philosophy of Education. The implementation of the Primary School Curriculum in 2010 brought a new dimension to the country's History curriculum. Through KSSR, the contents of the History curriculum are presented as a group of information as well as an approach towards knowledge implementation (Ministry of Education Malaysia 1990). History is one of the core subjects in Primary School Curriculum (KSSR) which was introduced in 2014. Under the new curriculum, the KSSR, history subject becomes a core subject that all Year 4 to 6 students must learn. This is an initiative that was taken after making History as a compulsory subject in SPM. History subject taught in primary schools will have continuity with the contents that will be later taught during high school. It also aims to instil students' interest in History subjects as well as providing students with a basic background in history as a preparation when entering secondary school.

Standard Curriculum for Primary School in History subject involves three levels, namely Year 4, Year 5 and Year 6. The content and theme of the history curriculum vary according to the breakdown of the theme and year. In line with the implementation of the Standard Curriculum for Primary School (KSSR) to replace the Integrated Curriculum for Primary School (KBSR), History subject has been the main subject for primary school since 2014. The creation of the History curriculum in the KSSR emphasizes cognitive, effective and psychomotor domains and implements new skills including thinking skills, information and communication technology skills, multidisciplinary skills, future studies and lifelong learning. History subjects form the core subjects of the Primary School Curriculum (KSSR), incorporating elements of citizenship, patriotism and constitution to ensure that students understand and appreciate the history of the country in depth and learn the subject whole heartedly. The general aim of the implementation is that these three elements will be applied to the teaching and learning of History subjects that use the concept of learning is fun'.

This history emphasizes the application of pure values, patriotic spirit, elements of citizenship and moral values in the hope that all of these elements can be applied by students in everyday life. The elements of citizenship and moral values embodied in the KSSR History are intended to form citizens with national identities that can further shape Malaysians with social cohesion, national integration and identity. Knowledge and understanding of History aspects can produce patriotic students by exposing them to maturely analysing and assessing historical facts.

a. The Goal of History KSSR 
The History Standard Curriculum for Primary School enables students to understand the human behaviour, actions and consequences, the uniqueness of the country's history and the glory of the nation in producing patriotic citizens and upholding the practice of democracy in Malaysia. History subject in KSSR also creating proactive, dynamic and progressive teachers as well as enhancing the understanding of the goals, objectives and contents of the curriculum.

\section{b. The Core of History KSSR}

The History Standard Curriculum for Primary is built based on six cores with the purpose of developing the Communication, Spirituality, Attitude and Values, Humanities, Balanced and Harmonious Individual, Knowledge of Science and Technology Literacy as well as Personal Skills.

\section{c. Focus and Form of the KSSR History Standard Curriculum}

The main focus of the KSSR History is to inculcate the knowledge and basics of History thinking skills as well as to apply patriotic spirit with the aim of producing and educating students to be a citizen with national identity and to understand the background and history of a country with social and national integration. The content of History subjects at the primary level aims to educate students to understand and appreciate their country's history by looking at the changes and its continuity that is still prevalent in Malaysian society.

Indirectly, this can expose students to analysing and assessing historical facts materially through knowledge of the past which highly influences the present. Through this learning, students can build a chronological framework for important events and personalities, make comparisons about human experience and, in turn, be able to understand individual role as a member of a society. A basic knowledge and understanding of the history of the country can lead to patriotic students by exposing them to facts evaluation. This situation will create a sense of love towards country and create a sense of pride as Malaysians.

\section{The Issue and the Problems in Implementing Self- Identity}

Malaysian society is multicultural, made up of many different cultural groups. According to Pye and Verba (1965), national identity is an individual's beliefs and is linked to how they perceive themselves as members of their country. The existence of national identities among members of a country is a culture based on the boundaries of nations.
Hence, we should not let differences hindering our racial unity.

Adolescents comprise more than half of all Malaysian population. Due to their high numbers, there are also problems associated with this group (Mahmood, 1994). Numerous statistical data show that moral collapse among adolescents in the country is becoming more severe. According to Bukit Aman Criminal Investigation Assistant (Daily News, September 22, 1993), between 1990 and 1992, a total of 37,602 individuals were arrested for property and violent crime offenses. Among these, 3,450 or $9.17 \%$ were committed by adolescents. According to a press release from Utusan Malaysia (4 August 1993), many of the teenagers who are morally defective are still in school. For example, in 1991 alone, 124 students were arrested for various crimes and the number of arrests increased over the years. According to statistics, crime cases involving teenagers increased significantly between 1990 and 1992. In 1990, 657 cases were recorded, followed by 830 cases in 1991 and 1487 cases in 1992 . Crimes committed by teenagers is not just happening in the cities or towns, but across the country.

Even more surprising is that the drug problem also does not seem to be decreasing. According to the latest statistics of the Anti-Drug Task Force (PPAD), of the 7,980 new addicts detected during January to September 1995, 1,311 or 16.4 percent were between 13 and 19 years old (Daily News, 5 February 1996). The Utusan Malaysia newspaper (March 27, 1996) also published a nationwide survey by the Ministry of Youth and Sports in January 1994 on 5,860 teenagers which showed 71 percent of these youths were smoking, 40 percent watching porn videos, 28 percent involved in gambling, 25 percent drinking alcohol and 14 percent doing drugs. The problems such as drugs abuse, Aids, loitering and bullying in the productive age of youths, are signals that personality development is not being adequately addressed, while life is changing rapidly. More worrying is that between 2000 and 2001, issues of adolescent moral morbidity did not recover and become even more severe. From this fact, one can conclude that the attitude of the people or adolescents in particular is still a troubling question. Although the people have acknowledged and voiced unwavering loyalty towards the Malaysian nation, the racial unity among citizens yet is still to be prospered. This is a very important issue to be solved from now on. According to Abd. Rahim (2001), the factors contributing to the above problem are the shallow basic knowledge on race, religion and national history, sensitive attitudes, influence and deception, diminished parental oversight, an increasingly individualistic society and declining focus on religious and moral education. It is hoped that through History subject, the 
elements of patriotism will be incorporated in schools, and aims to uphold their moral values.

According to Wong (2005), the issue of diminishing nationalism among young people today is due to the lack of awareness among them about the challenges they must face in order to fulfil their responsibilities as citizens. This is because they are a generation that is born after independence and enjoy all the available opportunities without realizing the challenges that the previous generations had to endure in their struggle to ensure that their grandchildren could enjoy liberty. It also triggers a 'complacent culture' among today's young people. All the luxuries and amenities provided by the family and the country do not make them feel threatened by the progress and achievements of other nations or countries. This culture engages some of today's young people in serious social problems. In order to create a true nation called Malaysians who are capable of presenting their own identities to compete with other nations, the people who share a characteristic of patriotic spirit are essential to highlight the nation's identity. These elements of patriotism must give the Malaysians a distinctive personality and at the same time enable them to stand and flourish as a modern nation that is able to claim its place among other nations in the world today as well as in the future.

\section{Self-Identity Concept in Students}

Self-identity is a word that has only been mentioned in recent years. The word self-identity is derived from two words, 'self' and 'identity'. According to the Dictionary (Kamus Dewan) (2010: 612 \& 354), 'identity' here is meant to be original, pure or incoherent while the word 'self' is a person or body owner.

Generally, identity is a unique trait or characteristic of many aspects such as customs, languages, cultures and religions that are at the core of shaping the personality of an individual or a nation. The use of the term National Identity is widely used to describe one's love for his country, the spirit of patriotism that exists towards the country as well as religion.

According to Siddiq (2009), identity means the original qualities or characteristics of a person or a nation that shape the identity and character of that nation. There are many factors that influence a nation's identity formation such as its natural state, environment, historical experience and beliefs. However, the most important factor is the religious factor. Religion supports and bases the mind which gives man a world-view or a clear and comprehensive view of himself, the Creator, nature as well as his role in this life.
Once these two words are combined as 'selfidentity', they convey the meaning of a unique and distinctive characteristic, in terms of customs, languages, cultures and religions that can be the core and emblem of the personality of an individual or a nation (Kamus Dewan Dictionary 2010: 613).

As Abdullah (2009) points out, the identity of a nation refers to the characteristics that distinguish one group from another and the individual's sense of belonging to the group. Wan Muhamad (2010) states that identity is also referred to one's true personality which is not only visible externally, but also the inner values that it holds.

In other countries writings, the closest thing to selfidentity is national identity. ChiHuang (2005) states that identity is a category of socially constructed membership involves matters such as sovereignty, territorial jurisdiction and citizenship. De La Torre (1997) and Matera et al. (2005, p. 83) defines national identity as "socio-psychological space of belonging, as an identification with some significant traits, and as a consciousness, more or less elaborated, of sharing a space of life". National identity is also defined as any cultural characteristic of a community that can be shared and distinguished from other groups (Desai, 2006). For Mendelsohn (2002), identity can be referred to two things; qualities and features that are shared within the community and how individuals define themselves.

Research on past studies has found that studies on National Identity are often associated with race or country. This is because identity is closely linked to the mould of one's nation, culture and government. This is supported by Burbank (2010) in a study involving 795 respondents from 2 different age cohorts who found that older people in German had higher levels of patriotism, national identity and ethnocentrism than younger generations.

In terms of ethnic groups, Tartakovsky's (2010) research on adolescents in Russia and Ukraine found that adolescents from the majority group had a more positive attitude towards the country and a stronger sense of identity.

In the Malaysian context, national identities need to be associated with ethnicity since national identities are often represented differently by different ethnic groups in a given country (Tan 2000). According to Desai (2006), national identity in the Malaysian context is closely related to ethnic composition as Malaysia is a multi-ethnic country. Collet (2007) in his study also stated that formal education obtained in public schools should be a place for learning and practicing national identity. 
The following are some of the findings on issues of national identity related to national love, patriotic spirit and understanding a country's history and national heritage. The Utusan Malaysia Special Unit conducted a survey of 200 respondents, of whom 89.5 per cent were of young people aged 15 to 30 years about history and general knowledge of Malaysia (Utusan Malaysia, October 28, 2010). The study concludes that teenagers today are less aware of history, ignorance towards nationalism and taking patriotism for granted. So how effective is the education system in the country in cultivating a sense of identity among its people?

Ramlah (2005) study found that only 70 per cent of respondents which comprising of students from tertiary institutions in the country were able to memorize the Pillars of the Nation (Rukun Negara) well. Meanwhile, the knowledge about the Rukun Negara is better among female respondents and from those living in the urban areas. In addition, the study also found that the level of willingness of respondents to sacrifice for the country was still low (Ramlah 2005). The study also reveals that the students from literature majors background receive more exposure towards Rukun Negara in their courses of study (Ramlah 2005).

Overall, issues on self-identity, especially those regarding national character that were described above, can provide an indication of the need for a higher level of identity among the younger generation today. Among the suggested elements of national identity development are the grasp on Islamic principles and morals, upholding the spirit of patriotism, defending the nation's cultural heritage, respecting social cohesion, being bold and wise in facing globalization challenges.

\section{Suggestions to Strengthen Students' Self-Identity}

Some of the suggestions that need to be made in strengthening student self-identity related to teacher's knowledge and environmental support, implementation of History curriculum in primary school as well as practicing Malaysian identity. Support for the teachers' environment can be done by providing complete infrastructure and administrative system. Teachers' knowledge on the other hand is related to history-based content, pedagogy and thinking skills. Next is the implementation of the History Subject Standard Curriculum for Primary School related to effective history teaching methods, textbook use, teaching aids and assessment. Whereas Malaysian identity is related to understanding human behaviour, actions and effects, the uniqueness of homeland, patriotic citizens and understanding of democratic practices.

\section{Environmental Support and Teacher Knowledge}

Although all parties need to play a holistic role in addressing student discipline and morale, teachers' role is more effective because students receive formal and systematic education (Abd. Rahim Abd Rashid, 2001). In successfully implementing this aspect of self-efficacy, teachers are important players in implementing this KSSR strategy. Teachers must first have the self-identity before implementing them to their students (Zakaria Kasa, Abdul Rahman Md. Aroff, Abdul Majid Isa and Rahil $\mathrm{Hj}$. Mahyuddin, 1996). Lickona (1991) describes teachers' responsibility as a model of self-efficacy, in which teachers need to be guardians, models and mentors, practice moral discipline, build democratic classes, teach cross-curricular values, use cooperative learning, build positive moral culture in schools and make the students' parents a partner. Several aspects were explored in this study to assess the level of support for the environment and knowledge of teachers in applying good values towards elementary school students.

\section{a. Infrastructure facility}

Infrastructure means the overall services and facilities needed for development (Mustafa et al., 2007). According to Hedges, Laine, Greenwalds (1994) and Tribus (1996), the resources of an organization such as financial resources, computer equipment and other facilities are closely intertwined in determining the standards and achievements of a school in the academic or curriculum. There are various types of ICTs and multimedia which are integrated into teaching and learning specially to disseminate information in various forms such as text, voice, images, graphics, animations and others. With the complete infrastructure facilities, it is hoped that teaching and learning in the classroom will ultimately produce quality students.

\section{b. School Management}

Schools need to play an important role in promoting identity by creating a stimulating environment and a positive school culture (Zakaria Kasa, Abdul Rahman Md. Aroff, Abdul Majid Isa and Rahil Hj. Mahyudding, 1996). Schools are not just about academic excellence but more about building and developing personal potential, especially the personality, values and morals of the students. According to Veugelers (2000) the nature of the school, the school environment and culture, teachers' personality and teaching experience will influence the role of the teacher to inculcate pure values which in turn will influence the development of personal values among students.

\section{c. Knowledge of Historical Content}

Content knowledge refers to a teacher's knowledge on the content of a subject. The construct of content knowledge is 
often used to explain teachers' understanding which will determine whether learning a particular subject will be easy or difficult, about conceptions, pre-conceptions and misconceptions that the students have (Shulman, 1986). Shulman and Grossman (1987) in the model of teacher basic knowledge have identified that teacher knowledge is derived from seven domains, namely: content knowledge, general pedagogical, curriculum, pedagogical content, pupils and their characteristics, educational contexts and educational goals. This includes knowledge on how certain topics in a subject should be taught with specific techniques that are different from other topics. The content of all the chapters needs to be neatly compiled, presented and tailored to the problem that the student is facing in order to understand the topics.

\section{d. History-Based Pedagogy}

Pedagogical knowledge refers to the knowledge on specific teaching strategies. Pedagogical Content Knowledge (PCK) is a unique knowledge and refers to the way teachers present content which makes it is easy to understand and promotes student's conceptual understanding. PCK involves the use of effective analogies, examples, explanations and demonstrations as well as taking into account student background (Tengku Zawawi et.al: 2009). This is in line with the definition given by Shulman (1987: 15) which defines PCK as a unique type of knowledge for a teacher and it is based on the way teachers relate pedagogical knowledge (knowledge of teaching) to content knowledge (what is taught). PCK is a teacher's understanding on how to help students understand a particular topic through a student's eye. PCK will assist teachers in making analogies, metaphors, examples, conducting various learning activities and demonstrations to give students better insight on the topics taught (Shulman 1986). Grossman (1990) explained that one domain of teacher knowledge is pedagogical content which contains four components, namely: Knowledge about the concept and purpose of teaching a subject, students' understanding, curriculum and learning strategies. For students, history subjects are one of the most boring subjects. Therefore, teachers need to actively engage students through the teaching and learning process. Teachers need to apply pedagogy skill that is different from the other subject and having high pedagogical skills to catch students' interest in studying history.

\section{e. History-Based Thinking Skills}

History subjects have systematic discipline core structure to enhance the teaching and learning process. History-based thinking skills are cognitive processes which allow students to explore complex abstract ideas with the guidance of teachers. This thinking skill also helps students to understand how historians integrate and deduce past events by using historical evidence to determine the significance of an event toward enhancing critical and creative thinking. The mastery of all the elements in this skill enables students to be empathy of historical events. History-based thinking skills are applied in almost all teaching and learning situations. Implementing historical ideas can help teachers to bring a sense of learning history that can further enhance the students' interest. This enables students to be more critical, creative and innovative. The basics of historical thinking skills that students need to master at elementary school are as follows: Elements of history (figure, place, events, date / time), concept of time (period, distance, specific date), time order (prefix, development and suffixes, measuring and calculating time calendars), time conversions (interpreting timelines, describing changes and continuations in time sequence), issues and past problems (studying causes, seeing changes and continuity, seeing causes and consequences), comparisons on the past (looking for similarities and looking for differences), imagination and empathy (visual imitation, developing creativity, imagination based on feelings), searching for resources (ways of finding sources, identifying sources, using sources) and significant evidence (dates of occurrence, figures involved, what happened, where / where it happened, how it happened). Learning History at the primary level as one of the formal subjects can stimulate students' thinking. Through teaching and learning, students will be able to understand critically and imaginatively all aspects of human life in the past and present with the element of empathy.

\section{The Implementation of History Subject Standard Curriculum for Primary School}

The teaching and learning approach of History subjects is focusing on critical, creative and innovative thinking skills through inquiry and exploration activities to strengthen understanding on History. The learning activities will apply an entertainment element to instil interest in History subjects. History subjects at the primary level are a continuation to their secondary level topics which acts as a dynamic science discipline. This is an effort to equip students with the development of knowledge, skills and practice of moral values as well as the application of their sense of identity as Malaysian citizens. There are several aspects that support the implementation of the history curriculum in the primary school curriculum including: strategy and planning, use of textbooks, teaching aids and summative as well as formative assessment.

\section{a. Effective History Teaching Methods}

The quality of education can be known from two things: the quality of the process and the product, but it seems that the current education does not pay much attention to this. The 
current curriculum places too much emphasis on the cognitive aspects and thus leaves little room for teachers to develop their full potential. While the purpose of education in Malaysia is to produce students, who are not only excel academically but also have a sense of moral values (Derap Guru, 2012: 34). Teachers need to plan their lesson first before they implement it in the classroom so that the learning process is directed and implemented as expected. This is conducted to ensure that the principles of History learning that have been incorporated into the teacher's lesson plan can be fully explained and implemented. With lesson planning, the teachers will have the concept and visualization of the material to be taught which ultimately to create quality learning and to educate students to not only excel in their cognitive skills but also in attitudes that reflect their values. citizenship, civic and patriotism.

\section{b. Textbook Use}

A learning material or source holds a vital role and one which is widely used is textbooks. Textbooks are important because of its role of not only as a source, but also as a medium of learning, the instrument for delivery of materials, assessment instruments, interest and motivation giver in students (Darwati, 2011: 76). Through textbooks, students are expected to learn facts, concepts, principles, laws, theories and other innovative ideas effectively in learning. This is because in today's age of globalization it requires knowledge and a wide range of skills so that the students can empower themselves to find, interpret, evaluate and use information, and to generate creative ideas for decision making. In its role of a very dominant a source of learning, textbooks were prepared and adjusted to the standard of competence and was crafted by taking into consideration of student's ability and cognitive development. Textbooks also serve not only as a source of learning, but also as a means of gaining students' interest and motivation. For this reason, there is a need for teachers to study more about the use of textbooks in teaching, especially in History subject. History textbooks are intended to provide awareness on historical events among students through the information presented which contains historical facts as well as moral values.

\section{c. Use of Teaching aids}

Teaching aids are important elements which facilitate communication between the teachers and students in the process of teaching and learning. Teachers therefore need to master all the knowledge and skills of preparing and using teaching aids in the teaching and learning process. The Ministry of Education's Integrated Curriculum for Primary School General Handbook (1988) clearly states the importance of using materials or media in the teaching and learning process in primary schools. The book describes three media functions: (i) helping teachers to create diversity and gaining interest in the lesson while providing opportunities for teachers to try other teaching approaches and techniques; (ii) help teachers to create more meaningful situations to convey the details of the lessons; (iii) help teachers to stimulate the students' skills such as thinking and speech as well as enable them to use one or more senses in solving a problem. In this regard, teachers need to play the role of director, mentor, manager and facilitator in the teaching and learning process.

\section{d. Ratings}

Summative and formative assessment model was firstly developed by Michael Scriven. This evaluation model shows the existence and scope of the objects being evaluated, namely, the evaluations that are performed while the program is running (formative) and when the program is complete (sumative) (Suharsimi Arikunto, 2004: 25). Formative assessments can be made by the teacher according to the needs and the purpose of this assessment is to determine the level of success or achievement for each competency. Whereas the summative assessment function is to evaluate the individual's position and performance as compared to the group. Due to the time differences in which objectives and summative are evaluated, the objectives of evaluations are also different (Arikunto, 2004: 26).

In conclusion, the support of the social environment, especially family, friends and the local community plays an important role in the involvement of youth in his spare time. Therefore, the responsibility for the family, friends and local communities is to improve and control the use of leisure time among the youth such as encourage them to participate in a program or to improve knowledge in the non-formal event, participate in sports and traditional recreational, volunteered in spiritual and religious related activities, participate in various family activities, and participate in various community programs and courses related to business and entrepreneurship.

\section{The Self-Identity Practice as A Malaysian}

The practice of self-identity as a Malaysia is related to understanding human behaviour, actions and consequences in History, the uniqueness of homeland, citizens' patriotism and the understanding of democratic practices.

\section{a. Understanding Human Behaviour}

In establishing the self-identity as a Malaysian citizen, students need to understand human behaviour in line with the goals of the Standard Curriculum for Primary School in teaching History. By embracing the behaviours that will be the role models, it is hoped that students will be able to distinguish between the good and bad behaviour. In addition, students need to understand racial position in the context of their location and formation to reinforce racial understanding. This in turn will lead to the avoidance of disruptive and non-disciplinary behaviour and can result in the formation of good behaviour (Alberto \& Troutman 1990, 
Bandura 1977, Skinner 1982, 1968, Axelrod 1983). By understanding behaviours, students with behavioural and disciplinary problems can develop positive and acceptable behaviours in school.

\section{b. Actions and Consequences in History}

The actions and consequences in history are intended to produce students who understand history before and after independence. In addition, students also need to understand past events through curiosity, identify various sources and historical information, understand ideas, concepts and elements of cause and effect in history, articulate historical significance in life by taking lessons from historical events in an effort to strengthen the harmonious atmosphere. Shemilt (1980) conducted a review of the national curriculum in the United Kingdom in "School Council Project History 13-16". What is emphasized in this project is that the nature of history, the use of resources and the active involvement of students have an impact on the concept of history among teenagers. In her research, Shemilt compared the achievements of 500 students who participated in this project with 500 other students who did not. The findings of the study show that students who follow this project have better grasp on important concepts in history.

\section{c. The Uniqueness of the Homeland}

Knowing the uniqueness of our homeland can instil a sense of national love. At this level, students are required to assess the country's heritage in the context of local, national and global level to evaluate the country's achievements in its political, economic and social progress. Wan Mohd. Zahid (in the preface of KBSM History textbook Form 1, 2004) hopes that this history textbook will foster a sense of love and loyalty to the nation among students and will help to produce young people who have always maintained national sovereignty while striving to advance and modernised our country.

\section{d. Patriotism and Citizenship}

The application of citizenship elements and moral values through the teaching of history in primary school education is aimed to produce a united, proud Malaysian citizen, loyal to the nation, passionate, disciplined, active in practicing and appreciating the qualities of patriotic citizens. Its implementation is comprehensive and integrated in line with the National Philosophy of Education. Applying citizenship elements and moral values will be conducted using Citizenship Dimensions. This element refers to a nation that inhabits a geographic environment that has an ethos as a link between the ethnic groups that inhabit it. In Malaysia, citizens are made up of different ethnicities, cultures and religions. Thus, the main aim is to apply citizenship elements and moral values in the history curriculum in order to create a patriotic citizen. Lack of patriotic spirit among the younger generation today is one of the reasons why some of them are more inclined to involve in unprofitable activities, such as engaging in a culture of hedonism (extreme entertainment / pleasure) because their souls are empty from values, religion, race and love towards the country (Ahmad, 2004).

\section{e. Understanding Democracy Practice}

By understanding democracy, students are aware of their responsibilities as Malaysian citizens. The practice of democracy is important to produce future leaders. According to Pye and Verba (1965), national identity is an individual's belief and it is expressed by how they perceive themselves as members of their country. The existence of national identity among members of a country is based on the boundaries of the country.

\section{Conclusion}

Effective History education can inculcate the spirit of selfidentity as Malaysian into the soul of the students, which means willingness to risk their lives to defend the country in order to reinforce the national ideology and make Malaysia a developed nation and live by the principles embodied in the Nations Pillar (Rukun Negara). The KSSR is definitely reflecting the country's aspirations and ideologies. History subjects is a highly dominant platform to produce citizens with high national identity, pride and carry responsibility as citizens. Having a KSSR History course will help the teachers to prepare and implement teaching and learning activities effectively. The application of Malaysian selfidentity can be realized through the content and learning standards which clearly expressing the government's determination to ensure today's generation to be intellectually, spiritually, emotionally, physically and prepared for the current globalization as well as equipped with 21 st century knowledge. Understanding local history can enhance the spirit of love towards the nation and understanding the nation's struggle, thus fostering unity and patriotism on the younger generation. However, to ensure the success of this curriculum transformation, it requires a strong commitment from everyone, including policy makers, implementers, curriculum managers, parents and stakeholders. Otherwise, the new curriculum will have no positive impact and will not achieve the outlined goals. Thus, the Ministry of Education Malaysia will continue to review the curriculum to ensure that curriculum implementation in the school will equip the students with the knowledge, skills and values to meet the current and future challenges and to implement self-identity and nation building which is a national vision for the future.

\section{References}

[1] Abdullah Mohd. Noor. 1986. Cabaran Profesionalisme Perguruan. Seminar Pendidikan Kebangsaan. Fakulti Pendidikan, Universiti Kebangsaan Malaysia. Bangi. 
[2] Abd. Rahim Abd. Rashid.1999. Pendidikan sejarah: Falsafah teori dan amalan. Kuala Lumpur: Utusan Publications \& Distributors Sdn. Bhd.

[3] Abd Rahim Abd Rashid. 2001. Nilai-nilai Murni Dalam Pendidikan : Menghadapi Perubahan dan Cabaran Alaf Baru. Kuala Lumpur. Utusan Publications \& Distributors

[4] Abd Rahim Abd Rashid. 2001. Perubahan Paradigma Nilai : Ke Arah Transformasi Sosial dan Pembentukan Malaysia baru. Kuala Lumpur. Utusan Publications \& Distributors

[5] Abd Sukor .2003. Pemupukan Semangat Patriotisme di Kalangan Pelajar Sekolah Menengah Menerusi Pengajaran dan Pembelajaran Sejarah : Satu Kajian Kes Tingkatan Dua. Tesis Sarjana: Universiti Pendidikan Sultan Idris

[6] Ahamad Rahim. 2011. Kurikulum sejarah kearah pembentukkan bangsa di Malaysia. Dlm. Proceedings International Seminar on Educational Comprative for Active Learning Between Indonesia and Malaysia. Universiti Malaya, Universiti Kebangsaan Malaysia dan Universiti Pendidikan Indonesia.

[7] Ahamad Rahim. 2012. Penilaian Perlaksanaan Kurikulum Sejarah Menengah Rendah Tingkatan 2. Tesis Dr. Fal. Universiti Kebangsaan Malaysia. Bangi

[8] Ahmad Talib. 1994. Penyediaan Guru Untuk Melaksanakan Kurikulum Sejarah KBSM: Satu Tinjauan Di Beberapa Buah Sekolah Menengah di Negeri Sembilan. Tesis Sarjana Kuala Lumpur: Universiti Malaya

[9] Arikunto, Suharsimi. 2001. Prosedur Penelitian: Suatu Pendekatan Praktek. Jakarta: Rineka Cipta.

[10] Awang Had Salleh. 2000. Patriotisme Dan Globalisme Dalam Konteks Pergerakan Bahasa Dan Sastera Kebangsaan. Dlm. Abdul Latiff Abu Bakar (pnyt.). Globalisme Dan Patriotisme Dalam Sastera Melayu: Kumpulan Kertas Kerja Hari Sastera. 1995. Kuala Lumpur: Dewan Bahasa dan Pustaka

[11] Cranbtree, C.1989. Improving History in the schools. Educational Leadership 47(3):25-28

[12] Darwati. 2011. Permanfatan Buku Teks oleh Guru dalam Pembelajaran Sejarah: Studi Kasus di SMA Negeri Kabupaten Semarang. Paramita. Vol. 21 910: 75-89.

[13] Gunasekaran Karapaya.1997. Pendidikan Sejarah Di Sekolah Menengah Rendah Di Malaysia: Satu Kajian Tentang Sejauhmana Buku Teks Sejarah Menepati Matlamat Pendidikan Sejarah. Tesis Sarjana Minden: Universiti Sains Malaysia

[14] Grossman, P. L. (1990). The Making of a Teacher: Teacher Knowledge and Teacher Education. New York: Teachers College Press.

[15] Farah Wahida dan Mohd Ayub.2012. Persepsi guru terhadap perlaksanaan Kurikulum Standard Sekolah Rendah (KSSR) dalam kalangan guru Tahun 1 Zon
Keramat Keramat. Dlm Prosiding Seminar Pasca Siswazah .Fakulti Pengajian Pendidikan, Universiti Putra Malaysia.

[16] Hedges, L, V., Laine, R. D., \& Greenwald, R. (1994). Does money matter? A metaanalysis of studies of the effects of differential school inputs on student outcomes. Educational Researcher, 23(3), 5-14.

[17] Ikhsan, O., \& Norila, M.S. 2005. Kurikulum \& Pengajaran Sekolah Rendah, Aspek-aspek yang Berkaitan. Tanjong Malim: Quantum Books.

[18] Ismail bin Said \& Rosadah binti Nik Ali. (2013). Kurikulum sejarah sekolah rendah. Kangar: IPG Kampus Perlis. Kementerian pendidikan Malaysia. (2003). Sukatan pelajaran kurikulum bersepadu sekolah rendah.

[19] Kementerian Pendidikan Malaysia. 2011.Kurikulum Standard Sekolah Rendah. Dokumen Standard Kurikulum dan Pentaksiran Sejarah Tahun 4, Putrajaya, Pusat Perkembangan Kurikulum.

[20] Kementerian Pendidikan Malaysia (KPM). 2015. Pelan Pembangunan Pendidikan Malaysia (PPPM) 2015-2025.

[21] Kementerian Pendidikan Malaysia. (1996) Undangundang Malaysia: Akta Institusi Pendidikan Swasta 1996 (Akta 555). Kuala Lumpur: Percetakan Nasional. Malaysia. 1986. Fifth Malaysian Plan 1986-1990. Kuala Lumpur: National Printing Department.

[22] Lickona, T. Educating for character: How Our Schools an teach respect and responsibility. New York: Bantam Books, 1991

[23] Lickona, T., The neglected heart: The emotional dangers of premature sexual involvment. American Educator (Summer, 1994)

[24] Mohamed Mustafa Ishak. 2002. Patriotisme dan Bangsa Malaysia. Dalam Idris Md. Noor et al. Patriotisme. Biro Tata Negara, JPM Malaysia

[25] Muhammad Ali Embi 2009 Patriotisme dan kepercayaan rakyat di Malaysia, utusan publications \& Distributors sdn bhd

[26] Najeemah Md Yusof, 2007. Konsep Pendidikan. Kuala Lumpur : PTS Profesional

[27] Nazri, M. \& Jamsari, A. 2002. Patriotisme: konsep dan pelaksanaannya di malaysia $1-9$.

[28] Nor Hartini Saari. (2008). Belia Hari Ini Cermin Masa Depan Negara. Dimuat turun pada 19/2/2010 daripada http:/www.ikim.gov.my/v5/index.php?cmd=resetall/grp= $2 \& \mathrm{key}=1603 \& \lg =1 \& \mathrm{opt}=\mathrm{com} \_$article \&sec $=$

[29] Poh Swee Hiang .2000. Kemahiran Berfikir Secara Kritis dan Kreatif. Kuala Lumpur: Kumpulan Budiman Sdn.Bhd.

[30] Rohana Zubir (1982). The History Teachers Dilemma : Fact or Fiction. Masalah Pendidikan. Jilid 9. Fakulti Pendidikan. Universiti Malaya

[31] Shulman, L.S. (1986). Paradigms and research programs for the study of teaching. In M.C. Wittrock (Ed.), 
Handbook of research of teaching (3rd ed.). New York: Macmillan.

[32] Tengku Zawawi Tengku Zainal. 2000. Kurikulum Matematik sekolah bestari. Jurnal Akademik Maktab Perguruan Kuala Terengganu 11: 4-144.

[33] Veugelers, W. (2000) Different ways of teaching values, Educational Review, 51, pp. 37-46.

[34] Zahara Aziz. 1985. Penerapan Pendidikan Kewarganegaraan dan Kesejahteraan Negara. Dalam Juriah Long. Aliran Dalam Pendidikan Menjelang Abad Ke 21. Bangi: Penerbit UKM

[35] Zakaria Kasa, Abdul Rahman Md. Aroff, Abdul Majid Mohd Isa, Rahil Hj. Mahyuddin. 1996. Penerapan nilainilai murni merentas kurikulum : Satu Tinjauan. Laporan Penyelidikan Kementerian Pendidikan Malaysia dan Fakulti Pengajian Pendidikan Universiti Pertanian Malaysia.

[36] Zulkifley Hamid. 2004. Bahasa Melayu sebagai bahasa penyatu dan bahasa pemisah warga Malaysia. The 4th International Malaysian Studies Conference 